НАУКОВИЙ ВІСНИК

Scientific messenger of Lviv National University of

7

(2)

औरा है

1 is 1 if

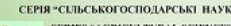

Том 22 № 92

2020
Науковий вісник Дьвівського національного університету ветеринарної медицини та біотехнологій імені С.3. Гжицького. Серія: Сільськогосподарські науки

Scientific Messenger of Lviv National University of Veterinary Medicine and Biotechnologies. Series: Agricultural sciences

UDC 502/504:574:379.8

\title{
Research of the natural resource and recreational potential of the Rohatyn district of Ivano-Frankivsk region
}

T. B. Nahirniak

Stepan Gzhytskyi National University of Veterinary Medicine and Biotechnologies Lviv, Ukraine

Article info

Received 14.02.2020

Received in revised form 16.03.2020

Accepted 17.03.2020

Stepan Gzhytskyi National University of Veterinary Medicine and Biotechnologies Lviv, Pekarska Str., 50, Lviv, 79010, Ukraine. Tel.: +38-063-387-66-95 E-mail:ntb08@ukr.net
Nahirniak, T. B. (2020). Research of the natural resource and recreational potential of the Rohatyn district of Ivano-Frankivsk region. Scientific Messenger of Lviv National University of Veterinary Medicine and Biotechnologies. Series: Agricultural sciences, 22(92), 93-98. doi: 10.32718/nvlveta9216

The current state of the components of the environment, the resource-recreational potential of the Rohatyn district of Ivano-Frankivsk region are analyzed. It is noted that the district has a sufficiently high integral indicator of anthropogenic environmental loads, nature management here is often irrational and ecologically unbalanced, and natural resource efficiency is rather low. The basis of restructuring of the economy of the Rohatyn region is to lay its investment and innovation model, taking into account the peculiarities of the region's potential, in particular the efficient use of its natural resource component. Although the Rohatyn region is not a rich region for natural resources, scientifically sound rational use of these resources should be an essential prerequisite for further socio-economic development. The absence of significant reserves of mineral raw materials gives rise to the search for another model of economic development of the region. At the same time, one should not forget about landscape and recreational resources, mineral water reserves, certain types of mineral resources. Such a model of its time was implemented in other regions through the formation of an appropriate sectoral structure of the economy, when the faces of economic development were determined by the sectors of processing of agricultural raw materials, agricultural machinery, services. Further development requires the development of programmatic actions to restore once destroyed production capacity, as well as the functioning of businesses that focus on the use of local resources. It is established that Rohatyn region has considerable potential for the development of the recreational and tourism industry. It is necessary to develop tourism infrastructure; to develop a holistic tourist product that is able to satisfy the needs of international and domestic tourism to the maximum, taking into account the natural-climatic, recreational, socio-economic and historical-cultural potential. As a central part of the Opilia region, the Rohatyn district has considerable historical and cultural potential, which should be more actively used for the development of cognitive tourism, for national and patriotic education of the population. Therefore, it is necessary to contribute in every way to the development of rural green tourism, which can be based on the use of both natural and historical and cultural resources of the region. To do this, it is necessary to contribute in every possible way to the preservation of unique places of nature, the creation of new and the discovery of little-known historical and cultural monuments, to develop patronage.

Key words: Rohatyn district, natural conditions, environmental components, pollution, natural resources, protection and balanced use, recreational activity.

\section{Дослідження природно-ресурсного і рекреаційного Рогатинського району Івано-Франківської області}

\author{
Т. Б. Нагірняк
}

Львівський національний університет ветеринарної медицини та біотехнологій імені С. 3. Гюсицького, м. Львів, Україна 
Проаналізовано сучасний стан компонентів навколишнього природного середовища, ресурсно-рекреаційний потенціал Рогатинського району Івано-Франківщини. Відзначено, щзо район має достатньо високий інтегральний показник антропогенних навантажень на навколишнє середовище, природокористування тут часто є нераціональним й екологічно не зрівноваженим, а ефективність використання природних ресурсів досить низька. В основу реструктуризації економіки Рогатинського району необхідно закладати інвестичійно-інновачійну ї̈ модель з урахуванням особливостей потенціалу регіону, зокрема ефективного використання його природно-ресурсної складової. Хоча Рогатинщуина і не є багатим на природні ресурси регіоном, однак науково обтрунтоване рачіональне їх використання має стати суттєвою передумовою подальшого сочіально-економічного розвитку. Відсутність значних запасів мінеральної сировини породжує пошук іншої моделі розвитку економіки краю. Водночас не можна забувати про ландшафтні та рекреачійні ресурси, запаси мінеральних вод, окремі види мінеральної сировини. Така модель свого часу була реалізована в інших регіонах через формування відповідної галузевої структури господарства, коли обличчя економічного розвитку визначали галузі переробки аграрної сировини, сільськогосподарське машинобудування, сфера обслуговування. Подальший розвиток потребує розробки програмних дій щцод відновлення колись зруйнованого виробничого потенціалу, а також функціонування суб'єктів господарювання, які б орієнтувалися на використання місчевих ресурсів. Встановлено, щзо Рогатинщина має значний потенціал для розвитку рекреаційно-туристичної галузі. Тут доцільно розвивати туристичну інфраструктуру; формувати иілісний туристичний продукт, який здатний максимально задовольнити потреби міжснародного і внутрішнього туризму з урахуванням природно-кліматичного, рекреаційного, соціально-економічного та історико-культурного потенціалу. Рогатинський район як центральний у складі Опільського регіону володіє чималим історико-культурним потенціалом, який має активніше використовуватися для розвитку пізнавального туризму, для національно-патріотичного виховання населення. Тому треба дбати про розвиток сільського зеленого туризму, який може базуватися на використанні як природних, так і історико-культурних ресурсів краю. Для цзього доцільно всіляко сприяти збереженню унікальних місць природи, створенню нових і виявленню маловідомих історикокультурних пам'яток, розвивати меценатство.

Ключові слова: Рогатинський район, природні умови, компоненти навколишнього природного середовища, забруднення, природні ресурси, охорона та збалансоване використання, рекреаційна діяльність.

\section{Вступ}

Діючі інвестиційні проекти природоохоронного призначення в Рогатинському районі спрямовані на охорону навколишнього природного середовища, екологічно безпечне використання природних ресурсів та забезпечення екологічної безпеки (Prohrama... 2016). Проте кількісно (наявність інвестиційних проектів) і якісно (величина екологічного ефекту) вони залишають бажати кращого.

Однією із галузей, яка в сучасних умовах починає відроджуватися в Україні, є рекреація. Вона забезпечує потреби населення у відпочинку й оздоровленні, $є$ стимулятором розвитку допоміжних та обслуговуючих галузей, а також важливим чинником, що впливає на рівень та якість життя населення. Для оптимального розвитку цієї галузі важливо вивчити стан ресурсного забезпечення, особливості використання рекреаційного потенціалу, розвиток туристичної інфраструктури, рівень кадрового забезпечення галузі, тобто рівень сформованості та структуру рекреаційного господарства.

Незважаючи на значну кількість наукових досліджень рекреаційної проблематики (Adamenko \& Prykhod'ko, 2000), відомо ще небагато комплексних характеристик рекреаційної діяльності у регіонах, які б повністю розкривали рекреаційно-ресурсний потенціал, структуру рекреаційного господарства та містили б напрямки розвитку різних видів рекреації на основі наявних ресурсів та із врахуванням як потреб регіону, так і зовнішнього попиту. Такі питання стають все актуальнішими у зв'язку із необхідністю євроінтеграції України, вагомим чинником якої $є$ туризм як галузь рекреаційного господарства. Своєчасним $є$ завдання комплексного дослідження рекреаційного господарства, чинників його формування і територіальної організації.

Регіон дослідження має вдосталь ресурсів для формування рекреаційного господарства. Серед них вирізняють природні, історико-культурні, соціально- економічні. За умови їх раціонального використання тут можуть розвиватися різні види рекреаційної діяльності. Тому важливим $є$ визначення найбільш оптимальних напрямків розвитку рекреаційної діяльності на основі раціонального використання рекреаційних ресурсів.

Мета статті - аналіз природних і рекреаційних ресурсів як об'єктивної основи розвитку рекреаційного комплексу регіону, обгрунтування шляхів охорони та найбільш оптимального їх використання.

\section{Результати та їх обговорення}

За кліматичним та агрокліматичним районуванням України Рогатинський район розташований у межах теплої агрокліматичної та вологої, помірно теплої агрокліматичних зон. Річний хід температури повітря у Рогатинському районі є континентальним. На території району річна сума опадів становить близько 700 мм, а сума активних температур - у межах 2400$2800{ }^{\circ} \mathrm{C}$. Такі термічні ресурси дозволяють вирощувати на території району пшеницю, кукурудзу, цукровий буряк, льон, овочеві та плодові культури.

У минулому році в Рогатинському районі оброблялося 37640 га ріллі, що становить 86,8 \% від загальної площі (43370 га). У галузі рослинництва працювало 104 сільгосппідприємства різних форм власності, якими було засіяно 24252 га ріллі, або 64,4 \% усієї посівної площі району. Проте варто зауважити, що у структурі посівних площ району в минулому році у всіх категоріях господарств технічні культури складали 24 \% (9032 га), що, звичайно, може мати негативні наслідки для грунтів регіону.

У Рогатинському районі прослідковується тенденція до зростання викидів забруднюючих речовин в атмосферне повітря, що пов'язано зі збільшенням виробництв і кількості автотранспорту.

Незважаючи на деяке сповільнення виробництв, район вважається екологічно небезпечною територією, де відбувається розсіювання викидів шкідливих 
речовин від Бурштинської ТЕС, підприємств хімії та нафтохімії міста Калуша (Radlovs'ka, 2012).

За даними Головного управління статистики в Івано-Франківській області, у 2019 році в атмосферне повітря області потрапило 205 тис. т забруднюючих речовин, що на 7,4 \% менше, ніж у 2018 році. Основними забруднювачами повітря залишаються підприємства міста Бурштина, на які припадає 82,9 \% загальнообласних викидів, частка підприємств міста Калуша складає 7,4 \%, а Рогатинського району - менше ніж 1 \%. Проте саме у 2019 році в Рогатинському районі збільшено обсяги викидів забруднюючих речовин у 2,7 разу.

У розрахунку на квадратний кілометр території області щільність викидів від стаціонарних джерел забруднення складала 14,7 т (у 2018 р. - 15,9 т). У територіальному розрізі найбільше в розрахунку на квадратний кілометр викинуто забруднюючих речовин у містах Бурштині (15,4 тис. т) та Калуші (232 т), а в Рогатинському районі - 1,8-0,9 т (площа району $\left.815 \mathrm{\kappa M}^{2}\right)$.

У розрахунку на одну особу в області в атмосферне повітря потрапило 149,6 кг забруднюючих речовин проти 161 кг у 2018 р. Найбільше забруднюючих речовин у розрахунку на одну особу викинуто підприємствами міст Бурштина $(11,1$ т) та Калуша $(227,8$ кг), у Рогатинському районі цей показник перебував у межах від 70 до 34 кг забруднюючих речовин на одну особу (населення складає близько 43 тис. осіб) (Ofitsiynyy sayt Holovnoho upravlinnya statystyky v Ivano-Frankivs'kiy oblasti).

Найбільшим забруднювачем атмосферного повітря в Рогатинському районі є Бурштинська ТЕС. Очистка димових газів від золи здійснюється в електрофільтpax $з$ проектним показником ефективності очистки 90\%. Через фізичну та моральну застарілість електрофільтрів їхня ефективність становить 70-90 \%. Оксиди азоту та сірки викидаються без очистки. В останні роки було проведено заміни та ремонт електрофільтрів декількох енергоблоків Бурштинської ТЕС, однак залишається невирішеним питання сіркоочистки.

В результаті грунтознавчих досліджень у межах Рогатинського району виявлені такі основні типи i відміни грунтів: темно-сірі опідзолені, світло-сірі опідзолені, сірі опідзолені, чорноземи опідзолені, дернові, лучно-чорноземні, лучно-болотні, болотні та болотно-торфові грунти.

Темно-сірі опідзолені грунти займають найбільшу площу в Рогатинському районі (38 \%), світло-сірі опідзолені грунти поширені на високих вузькохвилястих плато та їхніх схилах.

Сірі опідзолені грунти поширені на менш розчленованих формах рельєфу, ніж світло-сірі. Чорноземи опідзолені оглеєні займають значні площі у районі (близько 32 \%). Зараз вони практично цілковито під сільськогосподарським використанням (рілля).

Дернові грунти на території району представлені різними відмінами щодо гранулометричного складу (піщані, глинисто-піщані) та ступенів прояву підзолистого та глейового процесів.

Лучно-болотні грунти поширені у днищах балок i на заплавах річок та потоків району. Болотні грунти разом $з$ болотно-торф'яними і торф'яними займають незначні площі й поширені на найнижчих рівнях заплав та днищ балок.

Під степовою рослинністю у південній частині району поширені чорноземно-лучні грунти на лесах. Колись вони входили до складу природних комплексів терас низького рівня, але зараз збереглися на незначних площах, в основному під об'єктами природно-заповідного фонду.

Земельний фонд району становить 81572 га. Землі сільськогосподарського використання займають найбільший відсоток площі - 71 \%, 3 них під ріллею $53 \%$, під сіножатями і пасовищами - 17 \% площі сільськогосподарських угідь. На жаль, така структура землекористування є першочерговою причиною розвитку процесів грунтової ерозії і оглеєння.

Але основною проблемою охорони грунтового покриву району $є$ захист від ерозії, розмивів, змивів, сповільнення розвитку процесу оглеєння та подолання наслідків попередніх меліорацій, якими на Рогатинщині було охоплено близько 2500 га земель.

Важливим аспектом в охороні грунтів району $є$ також ренатуралізація еродованих земель, невжитків шляхом відтворення лук і лісів. Так, за даними Управління екології та природних ресурсів в ІваноФранківській області, яке базується на пропозиціях районної влади, у Рогатинському районі створення лук передбачається на орних землях площею 3023 га, 3 яких під сіножаті планується перевести 2339, а під пасовища - 684 га.

У Рогатинському районі площа 13 заповідних об'єктів складає 289,4 га, що становить 0,35 \% площі району і лише 0,16 \% площі заповідних об'єктів Івано-Франківщини. Серед 13 природоохоронних об'єктів, що розташовані на території району, лише один має загальнодержавний статус ботанічної пам'ятки природи, всі інші - це об'єкти місцевого значення: лісові заказники (2), ботанічний заказник (1), гідрологічні заказники (2), ботанічна пам'ятка (1), комплексна пам'ятка природи (1), заповідні урочища (4). У них охороняється 21 вид рослин, занесених до Червоної книги України.

Серед тварин, які трапляються на Рогатинщині, до Червоної книги України занесені: тхір степовий (Putorius eversmanni Less.), ховрах рябий (Citellus suslicus Guld.), які трапляються в лучно-степових угрупуваннях. В урочищі "Гузів" Букачівського лісництва Рогатинського ДЛГ виявлено гніздування лелеки чорного (Ciconia nigra L). Журавель сірий (Grus grus L) охороняється у заповідних урочищах “Журавеньківське" та "Козарівське". Окрім цього, у північній частині району трапляється підковоніс малий (Rhinolophus hipposideros). Серед тварин, місцезнаходження яких підтверджене на території району, відсутні тварини, які занесені до Європейського червоного списку тварин і рослин, що перебувають під загрозою зникнення у світовому масштабі. Для охорони мисливської фауни у Рогатинському районі створено розплідник площею 59 га у Букачівському лісництві.

Поруч з Рогатином, праворуч від траси на Бережани - Чортова Гора (350 м над рівнем моря), це уніка- 
льна ботанічна пам'ятка природи, залишок льодовикового періоду, тут охороняється унікальний для Прикарпаття природний осередок лучно-степової рослинності на площі 13 га.

У районі - проблема грунтів, які були меліорованими. Водна меліорація супроводжувалася осушенням боліт і заплавних земель, спрямленням та поглибленням русел потічків і малих річок (площа болотних грунтів дорівнює 280 га). Це призвело до прискореного скидання води в гідрографічну мережу, втрати цілої низки природних регуляторів i резерваторів води, зниження рівня грунтових вод $\mathrm{i}$, як наслідок, до обміління річок, зменшення біорізноманіття.

Загальна площа, яку займають поверхневі води у Рогатинському районі, становить 1417 га, у Рогатині 31 га. Район розташований у басейні річки Дністер. На території Рогатинського району р. Дністер має дуже малу протяжність: він входить на територію району біля с. Журавеньки і виходить біля с. Козари. Площа водозбору річки в крайньому створі з Львівською областю в с. Журавно становить 11650 км².

Через м. Рогатин протікає річка Гнила Липа, яка є найбільшою лівою притокою Дністра у межах ІваноФранківської області. Система Гнилої Липи сильно розгалужена, вона має низку приток, ії долина широка, але береги характеризуються значною крутизною i висотою, порізані ярами і балками, зазвичай безлісі та розорані.

В регіоні залишається актуальною проблема малих річок $з$ огляду на наслідки скидання комунальних i промислових стоків, вирубування дерев і неконтрольованого ведення сільського господарства - розорювання берегів.

Оцінюючи санітарний стан основних річок району, можна відзначити, що протягом останніх років він загалом дещо поліпшився через зменшення обсягів водоспоживання і водовідведення забруднених стоків внаслідок скорочення промислового виробництва, а також поголів'я ВРX.

Зокрема, питома вага валової продукції тваринницької галузі за минулий рік становила 42,6 \% від усієї валової продукції сільського господарства. Протягом року чисельність худоби в сільськогосподарських підприємствах збільшилась на 47,8 \% і становить 1875 голів, в тому числі поголів'я корів відповідно зросло на 18,9 \% і складає 472. На фермах району утримується 563 голів м'ясного напрямку продуктивності, або в 2,5 разу більше, ніж на початку минулого року. У районі проводиться певна робота щодо реконструкції тваринницьких приміщень для утримання ВРX і свиней, а також щодо вдосконалення системи утилізації стоків.

Галузь лісового господарства та лісопереробки в районі представлена Державним підприємством "Рогатинське лісове господарство”, промислововиробничим підприємством "Укрлісекспорт", а також низкою столярних цехів і пилорам. Основним видом діяльності держлісгоспу є забезпечення ефективного використання та відновлення наявного лісового господарства на території району. Також підприємства займаються переробкою деревини та виробництвом пиломатеріалів.
Катастрофічне становище склалось в лісах, що перебувають в користуванні сільськогосподарських підприємств, які в процесі земельної реформи опинилися поза межами їхнього користування. Допускаються масові самовільні рубки, захаращеність лісових насаджень вітровально-буреломною деревиною, що значно погіршує санітарний стан насаджень.

Зважаючи на тектонічну прив'язку Рогатинського району до Східно-Свропейської платформи, тут переважно локалізовані неметалічні корисні копалини. Так, на території району поклади торфу локалізовані на землях Долинянської сільської ради, це родовище розроблялося Івано-Франківським торфопідприємством.

До групи будівельних матеріалів, що видобуваються чи локалізовані на території району, належать гіпс, ангідритовий камінь, піски стекольні та будівельні, пісковики, вапняки, глина біла і червона. Поклади гіпсу на території району підпорядковуються зональному проходженню у Східно-Свропейській платформі гіпсової зони. Родовище гіпсу локалізоване біля с. Колоколин, де також добувають ангідритовий камінь. Піски стекольні добувають біля с. Стратин, с. Кліщівна, пісковики - у Липівці. Окрім цього, в с. Лопушна розташовані вапнякові кар'єри, біля с. Липівка $\epsilon$ кар'єри будівельного каміння та піску, які також локалізовані біля с. Руда.

Мінерально-сировинний потенціал району використовують ще безсистемно та неефективно. Кризова ситуація в економіці призвела до різкого скорочення виробництва майже всіх без винятку видів продукції.

Розробку родовищ корисних копалин проводять у районі залежно від матеріально-технічної забезпеченості надрокористувачів, що призводить до непланомірного видобування мінеральної сировини і несвоєчасного проведення всіх інших робіт. На багатьох родовищах корисних копалин неякісно проводять розкривні роботи. Родючий шар грунту не знімається або знімається не на повну потужність, переміщується у відвали разом з підстилаючими породами. Відведені земельні ділянки часто не відмежовані на місцевості, що створює передумови для самовільного захоплення земель. Надрокористувачі несвоєчасно повертають відпрацьовані землі до використання за попереднім призначенням. Місцеві ради та органи виконавчої влади на місцях недостатньо здійснюють державний контроль за використанням і охороною надр у межах своєї компетенції.

Причинами неефективності інвестиційних проектів у мінерально-сировинній сфері Рогатинського району часто є відсутність на підприємствах спеціалістів гірничої служби, необізнаність відповідальних працівників підприємств з чинними нормативними документами у гірничодобувній галузі, в окремих випадках - безвідповідальне ставлення керівників підприємств і організацій до забезпечення виконання природоохоронного законодавства, неплатоспроможність більшості надрокористувачів.

Водозабезпечення господарського комплексу району проводять з підземних (свердловини, каптовані джерела, колодязі) і поверхневих (річки, струмки, ставки, водосховища та ін.) джерел. 
Загальна кількість ставків у Рогатинському районі складає 68, площа водного дзеркала - 228 га. Найбільше водосховище Рогатинського району - Княгиницьке площею 6,465 га.

В місті Рогатині діє централізована, повна, роздільна система каналізації. Метод очистки стічних вод - повна біологічна очистка із застосуванням аеротенків. Очищена стічна вода скидається в р. Гнилу Липу за межами міста внизу за течією. Загальна довжина каналізаційних колекторів і мереж в районі складає 5,2 км, 3 них 0,3 км є аварійними.

На території Рогатинського району $є$ одне родовище підземних питних вод, що перебуває на обліку в Державному фонді родовищ України - це Пуківське родовище. Вода цього родовища гідрокарбонатносульфатно-кальцієво-натрієвого складу 3 мінералізацією 0,2-0,8 г/л використовується для забезпечення водопостачання м. Рогатина. Основним джерелом водопостачання сільського населення є підземні води першого від поверхні водоносного горизонту (криниці).

До лікувальних мінеральних вод належать природні підземні води 3 мінералізацією понад 8 г/л для всіх хімічних груп і понад 15 г/л - для гідрокарбонатних і хлоридно-гідрокарбонатних вод, а також води меншої мінералізації при вмісті в них біологічно активних мікроелементів (J, F, Li та інші) на рівні галузевого стандарту України "Води мінеральні лікувальHi”.

Таким вимогам відповідає лише одне родовище лікувальних вод, що розташоване на території області - родовище сульфідних (сірководневих) вод бальнеологічного курорту Черче у Рогатинському районі. Мінеральна вода Черченського курорту має у своєму складі біологічно активну сполуку - сірководень, на території курорту також виявлено лікувальні торф’яні грязі.

Окрім лікувальних мінеральних вод, на території Рогатинського району виявлені джерела мінеральних питних вод. До державного стандарту України "Води мінеральні питні" на території Івано-Франківської області зачислено12 джерел групи лікувальностолових вод, мінералізація яких перебуває в межах від 1 до 8 г/л. Одне 3 таких джерел розташоване на території району - джерело води "Рогатинська", яке перебуває в експлуатації у с. Лучинці.

На території району також виявлено джерела мінеральних вод, які занесені до державного стандарту України "Води мінеральні питні" 3 мінералізацією до 1 г/л і різним іонним складом. Так, в с. Пуків є джерело мінеральної питної води "Роксолана", в с. Бабухів - "Рогатинська джерельна", в с. Воронів - "Перлина Прикарпаття" і “Перлина заходу".

У Рогатинському районі відомі Підмихайлівське родовище підземних питних вод, яке перебуває на обліку в Державному кадастрі родовищ України (вода гідрокарбонатно-сульфатно-натрієвого складу 3 мінералізацією 0,2-0,8 г/л), а також джерело сірководневих вод у смт Букачівці. Варто зазначити, що $є$ потреба в детальнішому вивченні та аналізі усіх виявлених джерел мінеральних лікувальних і питних вод, зокрема й джерел йодо-бромних вод, а також дослідженні обсягу запасів усіх розвіданих родовищ вод, що значно вплинуло б у майбутньому на розвиток оздоровчої діяльності 3 перспективою створення низки нових закладів державного значення.

Констатуємо, що в регіоні загалом сприятливі умови для розвитку оздоровчо-відпочинкового комплексу, проте найбільш значними серед рекреаційнотуристських ресурсів на цій території $\epsilon$ історикокультурні ресурси. Вони представлені пам'ятками архітектури, археології, різноманітними пам'ятниками та пам'ятними місцями історичних подій, пам'ятниками видатним людям і музеями.

Отже, на основі поєднання різних видів рекреаційних ресурсів, а саме: водних та мінеральних, історико-культурних, територія району є сприятливою для розвитку таких видів туризму: лікувальнооздоровчого, відпочинкового, культурно-історичного, екскурсійного та науково-пізнавального.

Цінність земельних і мінерально-сировинних ресурсів не применшує економічного й екологічного значення водних, лісових, рекреаційних ресурсів, тваринного й рослинного світу для створення належних умов життедіяльності та збалансованого розвитку. Характеризуючи природно-ресурсний потенціал, його не можна розглядати без урахування особливостей розвитку, а також соціально-економічного та ресурсно-екологічного стану країни.

\section{Висновки}

3 метою поліпшення стану довкілля у Рогатинському районі необхідно забезпечити раціональне використання природних ресурсів (землі, води, надр, лісів), їхню охорону від забруднення і виснаження, досягти зменшення викидів в атмосферне повітря шкідливих речовин, реалізації заходів щодо зберігання та утилізації відходів, а також вдосконалювати систему моніторингу довкілля, інформування населення про його стан, запобігати негативному впливу стихійних явищ, активізувати екологічну освіту i виховання.

Рекреаційно-туристична галузь району має складну компонентно-функціональну структуру, в ній виділяються пізнавальний, сакральний, лікувальнооздоровчий, спортивний, сільський - зелений, розважальний та інші види туризму. На даний час переважає внутрішній, пізнавальний туризм, об'єктами якого є природні й історично-культурні об'єкти загальнонаціонального значення, що розміщені у містах $\mathrm{i}$ селах $з$ добрим транспортним сполученням.

Регіон має значні можливості для розвитку сільського зеленого туризму (мальовничі ландшафти, висока густота сільського населення, збережена самобутня культура мешканців), однак цей вид туризму тривалий час перебуває у зародковому стані. Кластер сільського зеленого туризму не надає належних умов для відпочинку іноземних туристів у сільській місцевості та потребує активізації діяльності його складових. Впорядкувати діяльність екотуристів, що відвідують заповідні об'єкти краю, можна, створивши екологічні стежки. 
Головними причинами того, що не в повному обсязі використовуються всі види рекреаційнотуристських ресурсів, є недостатня увага до розвитку рекреаційної діяльності з боку місцевих органів влади i самоврядування, бізнесових структур, невисокий попит на рекреаційно-туристські послуги населення регіону і України загалом, що пов'язано з невисокими прибутками людей.

Перспективи подальших досліджень. Зростання обсягів використання природних ресурсів, їх вичерпання та деградація зумовлюють необхідність розробки та реалізації стратегії і тактики невиснажливого природокористування і постійного контролю за змінами у ході природних і антропогенних процесів для інтегрального управління природними ресурсами та станом довкілля.

\section{References}

Adamenko, O. M., \& Prykhod'ko, M. (2000). Rehional'na ekolohiya i pryrodni resursy (na prykladi IvanoFrankivs'koyi oblasti). Ivano-Frankivs'k (in Ukrainian).

Ofitsiynyy sayt Holovnoho upravlinnya statystyky v Ivano-Frankivs'kiy oblasti [Elektronnyy resurs]. Rezhym dostupu: http://www.ifstat.gov.ua (in Ukrainian).

Prohrama sotsial'no-ekonomichnoho i kul'turnoho rozvytku Rohatyns'koho rayonu na 2016 rik. Rohatyn (in Ukrainian).

Radlovs'ka, K. O. (2012). Doslidzhennya ekolohichnoho stanu hruntiv Rohatyns'koho Opillya. Naukovotekhnichnyy zhurnal, 2(6), 81-84. http://nbuv.gov.ua/UJRN/ebzp_2012_2_14 (in Ukrainian). 